Reprod. Nutr. Dévelop., 1982, 22 (3), 465-473.

\title{
Macroscopic classification of bovine follicles and its validation by micromorphological and steroid biochemical procedures
}

\author{
Th. A. M. KRUIP, S. J. DIELEMAN
}

Clinic for Veterinary Obstetrics, A.I. and Reproduction, State University of Utrecht,

Yalelaan 7, de Uithof, 3508 TD Utrecht, The Netherlands

\begin{abstract}
Summary. Bovine antral follicles ranging between 2 and $20 \mathrm{~mm}$ in diameter were dissected free of stromal tissue and classified under a stereomicroscope using criteria similar to those of Moor et al. (1978). For light-microscopic evaluation of the macroscopic classification, 191 follicles were fixed in Bouin's fluid, embedded in paraffin, sectioned through the cumulus and oocyte and stained with haematoxylin-eosin. To study the relation between the macroscopically determined morphological characteristics and the oestradiol$17 \beta$ (E2) level in the follicular fluid (FF), 39 follicles of one animal were selected. The E2 level, expressed as $\mathrm{pmol} / \mathrm{ml}$ of $\mathrm{FF}$, was estimated by RIA. The overall correlations between macroscopic classification and histological qualification of non-atretic and atretic follicles were 93.3 and 95.5 p. 100, respectively. Furthermore, the results indicated that the E2 level of small non-atretic follicles was lower than that of larger follicles and that the level in the FF decreased with increasing degeneration. It is concluded that macroscopic criteria offer a highly reliable means of identifying bovine follicles in terms of both micromorphology and functionality.
\end{abstract}

\section{Introduction.}

The study of the function of the follicular wall in oocyte maturation can be intensified in a reliable culture system for follicles. Since non-atretic follicles and those in different stages of atresia are present in the ovary at all stages of the oestrous cycle (Rajakoski, 1960 ; Brand and de Jong, 1973) and because follicles can become atretic or regenerate in culture (Hay et al., 1979), the reliability of macroscopic criteria depends on an accurate classification of the intact follicle shortly before culture begins. The first requirement is to evaluate the selected macroscopic criteria by micromorphological examination. The criteria used by Moor et al. (1978) for comparing the macroscopic appearance and the micromorphological features of ovine follicles offer a reliable means for identifying non-atretic and atretic follicles. The purpose of the present study was to apply these criteria to the classification of bovine follicles. To investigate whether or not the macroscopically determined morphological characteristics reflected their functionnal character, the oestradiol-17 $\beta$ level in the follicular fluid of a limited number of bovine follicles was estimated. 
Material and methods.

Antral follicles between 2 and $20 \mathrm{~mm}$ in diameter were dissected from the ovaries of cycling cows and heifers and kept on crushed ice until further examination. The follicles were dissected nearly free of stromal tissue by means of very fine watchmaker's forceps and classified under a stereomicroscope using the criteria described by Moor et al. (1978).

Follicles were classified as non-atretic if they had a uniformly bright appearance, extensive and very fine vascularisation, a regular granulosa layer and no free-floating particles in the follicular fluid. Follicles with some loss of translucency and a slightly greyish appearance or with some very small freefloating particles in the follicular cavity were classified as light-atretic. As the difference between these two classes was very small, a group of doubtful follicles was classified as indeterminate. Follicles were classified as atretic if they had a dull, grey appearance, blood vessels either irregularly filled with clotted blood or empty, partial detachment of the membrana granulosa and many large free-floating globules in the antral cavity. Follicles with a dark, often spotted, appearance and a very dark cumulus were classified as heavy-atretic.

The diameter of the follicle was measured with a micrometer in the eyepiece. For light microscopy, 191 follicles were fixed in Bouin's fluid, embedded in paraffin, sectioned through the cumulus and oocyte into 7- $\mu \mathrm{m}$ sections and stained with haematoxylin-eosin ( $\mathrm{H} \& \mathrm{E}$ ). In addition, small parts of preovulatory follicles, collected after the onset of oestrus, were similarly fixed, embedded and stained.

The dissected follicles all contained the membrana granulosa, the theca interna and up to ten layers of stromal cells (theca externa). The micromorphological criteria used to classify follicles were :

1. the presence or absence of degenerated cells or atretic bodies in the membrana granulosa and follicular cavity ;

2. the presence or absence of mitotic figures in the cumulus oophorus and mural layer of the membrana granulosa and theca interna ;

3. the organization and thickness of the membrana granulosa ;

4. the continuity or discontinuity of the basal lamina.

Although it is important to emphasize that follicular atresia is a complex process and depends on interactions between theca, granulosa and oocyte, only the above criteria were used for evaluation of the macroscopically classified follicles.

The section that contained the cumulus and the oocyte was micromorphologically evaluated. This section was not exactly a midline section. The number 
of degenerate cells or atretic bodies counted in one section was therefore multiplied by a factor, $X$, which varied from 1.1 to 1.3 :

$$
X=\frac{\text { follicule diameter }}{\text { diameter of section }+10 \text { p. } 100 \text { shrinkage }}
$$

To express the steroid levels as $\mathrm{pmol} / \mathrm{ml}$ of follicular fluid (FF) (table 2) and steroid production in vitro as $\mathrm{pmol} / \mathrm{ml}$ of protein (planned studies), we studied the relationship between classification, follicular diameter (corrected for percentage of flattening), total follicular weight and the weight cum protein content of the follicular wall. The total weight, volume of follicular fluid and weight of the follicular wall were determined for a group of 783 follicles.

For 316 follicles taken at random from the above group, the protein content of the follicular wall was determined according to the method of Lowry et al. (1951). The flattening of the dissected follicles was determined by comparing the measured diameter and the expected diameter, calculated from the total weight (spec. gravity $=1$; volume $=4 / 3 \pi r^{3}$ ).

To study the relationship between the macroscopically determined morphological characteristics and the oestradiol-17 $\beta$ level in the follicular fluid, 39 follicles of one animal in the follicular phase of the oestrous cycle were selected to rule out variations due to the possible influence of the day of cycle and to differences between animals. The oestradiol- $17 \beta$ level, expressed as $\mathrm{pmol} / \mathrm{ml}$ of follicular fluid, was estimated by radioimmunoassay according to Kruip et al. (1979).

\section{Results.}

\section{Macromorphological evaluation.}

Of the 191 follicles examined, 45 were macroscopically classified as nonatretic, 36 as indeterminate, 48 as light-atretic, 44 as atretic and 18 as heavyatretic (table 1). All preovulatory follicles were macroscopically classified as lightatretic or even atretic.

\section{Micromorphological evaluation.}

- Of the 45 macroscopically classified non-atretic follicles, 36 had the following features : 1) absence of degenerated cells and atretic bodies ; 21 many mitotic figures in the cumulus oophorus as well as in the mural layer of the membrana granulosa ; 3) a well-organized-membrana granulosa ( 8 to 15 cell layers); 4) a continuous basal lamina ; 5) mitotic figures in the theca interna, well-organized glandular cells and capillaries and, 6) in those sections where visible (24 out of 45), a healthy oocyte in germinal vesicle (GV) stage.

Follicles with these features were qualified as non-atretic (fig. 1). The remaining 9 follicles had the same features, except that some atretic bodies were seen in the membrana granulosa ; in 6 follicles the number of these bodies was 
TABLE 1

Relation between the macroscopic classification and microscopic qualification of bovine follicles

\begin{tabular}{|c|c|c|c|c|c|c|}
\hline $\begin{array}{c}\text { Foll. } \\
\text { diam. } \\
\text { (in } \mathrm{mm} \text { ) }\end{array}$ & $\begin{array}{l}\text { Macroscopic } \\
\text { classification }\end{array}$ & $\begin{array}{c}\text { Number } \\
\text { of } \\
\text { foll. }\end{array}$ & $\begin{array}{l}\text { non- } \\
\text { atr. }\end{array}$ & $\begin{array}{l}\text { Histologice } \\
\text { prim. } \\
\text { atr. }\end{array}$ & $\begin{array}{l}\text { alification } \\
\text { sec. } \\
\text { atr. }\end{array}$ & $\begin{array}{l}\text { tert. } \\
\text { atr. }\end{array}$ \\
\hline $2-5 \ldots \ldots \ldots$ & $\begin{array}{l}\text { non-atretic } \\
\text { indeterminate } \\
\text { light-atretic } \\
\text { atretic } \\
\text { heavy-atretic }\end{array}$ & $\begin{array}{r}10 \\
1 \\
20 \\
23 \\
15\end{array}$ & $\begin{array}{r}10 \\
1 \\
4\end{array}$ & $\begin{array}{l}16 \\
10\end{array}$ & $\begin{array}{r}13 \\
4\end{array}$ & 11 \\
\hline $5-8 \ldots \ldots \ldots$ & $\begin{array}{l}\text { non-atretic } \\
\text { indeterminate } \\
\text { light-atretıc } \\
\text { atretic } \\
\text { heavy-atretic }\end{array}$ & $\begin{array}{r}21 \\
16 \\
15 \\
14 \\
1\end{array}$ & $\begin{array}{r}18 \\
5\end{array}$ & $\begin{array}{r}3 \\
11 \\
10 \\
3\end{array}$ & $\begin{array}{l}5 \\
6\end{array}$ & $\begin{array}{l}5 \\
1\end{array}$ \\
\hline$>8$ & $\begin{array}{l}\text { non-atretic } \\
\text { indeterminate } \\
\text { light-atretic } \\
\text { atretic } \\
\text { heavy-atretic }\end{array}$ & $\begin{array}{r}14 \\
19 \\
13 \\
7 \\
2\end{array}$ & $\begin{array}{r}14 \\
4 \\
1\end{array}$ & $\begin{array}{r}15 \\
11 \\
1\end{array}$ & $\begin{array}{l}1 \\
5\end{array}$ & $\begin{array}{l}1 \\
2\end{array}$ \\
\hline
\end{tabular}

less than 5 and in 3 follicles it was between 5 and 10 . As the presence of some pyknotic nuclei $(<5)$ in the membrana granulosa should not be interpreted as a sign of degeneration but as a normal feature, according to the publications of Hay et al. (1976) and Driancourt et al. (1981), the 6 macroscopically-classified non-atretic follicles with less than 5 pyknotic nuclei per section were considered as non-atretic (table 1). The remaining 3 follicles were qualified as follicles of primary atresia.

- Of the 48 macroscopically classified light-atretic follicles, 37 showed the following features: 1) more than 5 and less than 50 degenerated cells and/or pyknotic nuclei bordering the antrum and less than 10 free-floating cells or atretic bodies in the follicular cavity ; 2) many mitotic figures in the cumulus oophorus and very few in the mural layer of the membrana granulosa. The other features were the same as those of non-atretic follicles. All the 22 follicles in which the oocyte was sectioned through the nucleus showed the GV stage. Follicles with these features were qualified as follicles of primary atresia (fig. 2). Of the remaining 11 follicles, 5 had less than 5 pyknotic nuclei besides the same features as non-atretic ones, and 6 had more than 50 degenerated cells in the membrana granulosa and some macrophages and pyknotic clumps in the follicular cavity which qualified them as follicles of secondary atresia.

- Of the 36 follicles classified as indeterminate, 10 had the same features as non-atretic follicles; the remaining 26 were identical to follicles of primary atresia. 

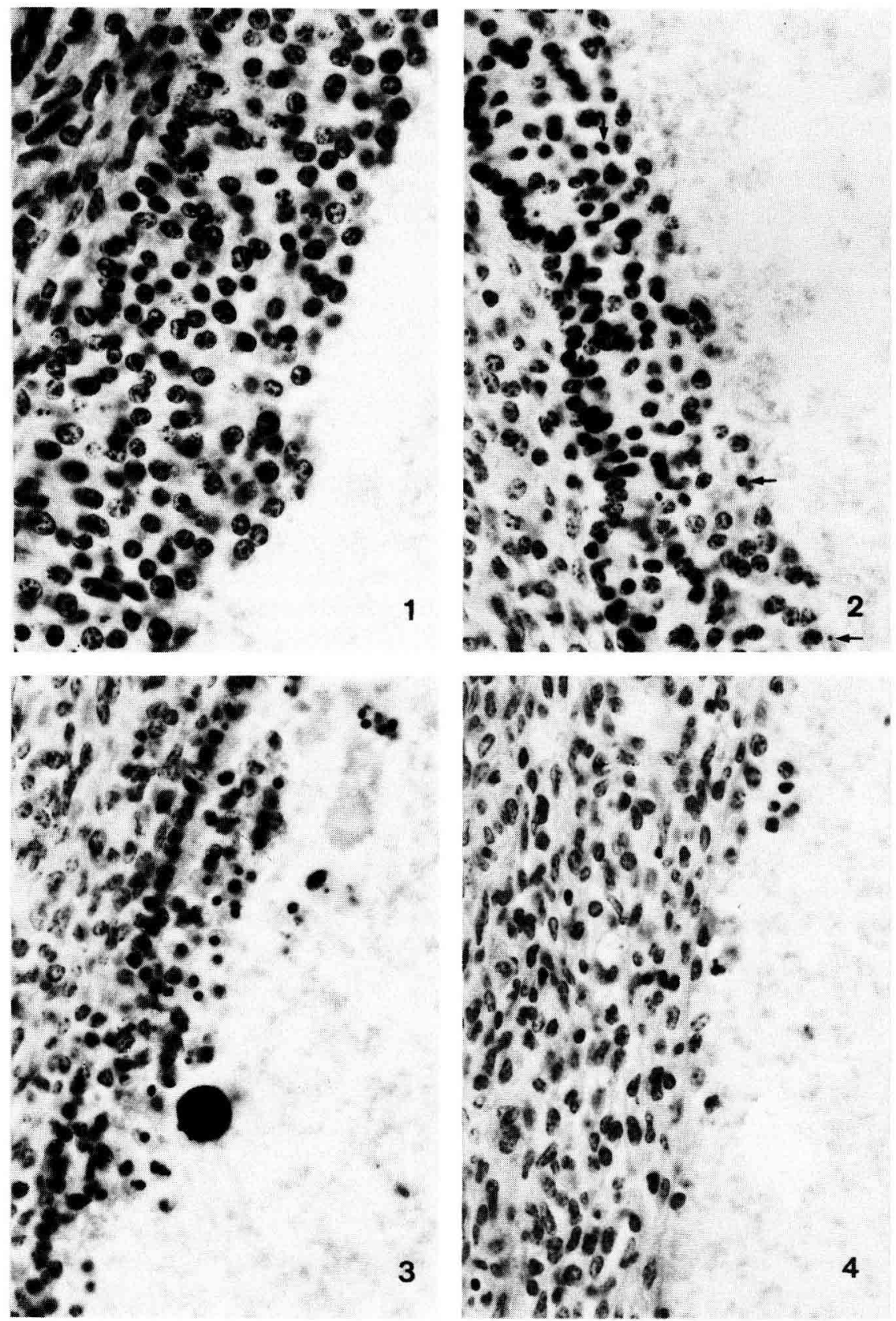

FIG. 1. - Granulosa layer of a non-atretic bovine follicle: apparently healthy granulosa cells. H \& E stain. $\times 400$.

FIG. 2. - Primary atresia in the membrana granulosa: some granulosa cells are degenerating, leaving nuclei and clumped chromatin (arrow) as atretic bodies. H \& E stain. $\times 400$.

FIG. 3. - Secondary atresia in the membrana granulosa : many pyknotic nuclei and large uniform atretic bodies. H \& E stain. $\times 400$.

FIG. 4. - Tertiary atresia in the membrana granulosa: nearly all granulosa cells have disappeared and very few pyknotic nuclei and atretic bodies are left. H \& E stain. $\times 400$. 
- Of the 44 follicles macroscopically classified as atretic, 24 had : 1) more than 50 pyknotic nuclei and degenerated cells in an often disorganized and thin membrana granulosa ( 1 to 10 cell layers) ; 2 ) no mitotic figures in the mural layer and very few in the cumulus oophorus; 3) many degenerated cells, macrophages and pyknotic nuclei and clumps in the follicular cavity ; 4) a discontinuous basal lamina; 5) some pyknotic nuclei in a rather well-organized theca interna and, 6) as far as sectioned (12), a healthy oocyte in GV stage. These follicles were qualified as follicles of secondary" atresia (fig. 3). Of the remaining 20 follicles, 14 had the same features as follicles of primary atresia and 6 showed no mural layer and many pyknotic nuclei in the cumulus oophorus. The latter follicles were qualified as follicles of tertiary atresia.

- Of the 18 follicles classified as heavy-atretic, 14 had : 1) some pyknotic nuclei, macrophages and degenerated cells bordering an often completely disappeared mural layer ; 2) a few free-floating cells and atretic bodies in the follicular cavity; 3) a degenerating cumulus oophorus with pyknotic nuclei ; of the 9 oocytes sectioned through the nucleus, 4 were healthy with the nucleus in GV and 5 were degenerated with either a star-like or a completely degenerated nucleus ; 4) a disorganized theca with swollen capillaries, without mitotic figures and with many pyknotic nuclei. These follicles were qualified as follicles of tertiary atresia (fig. 4). The remaining 4 follicles of this group had features more or less similar to follicles of secondary atresia.

The overall correlations between the macroscopic classification and the histological qualification of non-atretic antral follicles and all three classes of atresia together were 93.3 and 95.5 p. 100 , respectively.

The correlations between gross classification of the three groups of atretic follicles and histological qualification of the primary, secondary and tertiary stages of atresia were $75.4,55.8$ and 77.7 p. 100, respectively. The preovulatory follicles classified as light-atretic or atretic did not show pyknotic nuclei lining the antrum but had an enormously extended theca interna.

\section{Relationship between diameter, classification and weight of the follicular wall.}

The relationship between diameter, macroscopic classification and weight of the follicular wall is presented in fig. 5 . The weight of the wall of non-atretic follicles was higher than that of indeterminate cum light-atretic and atretic cum heavy-atretic follicles $(P \sim 0.1$ and $\sim 0.05$, respectively). The weight of the wall of indeterminate cum light-atretic follicles was higher $(P<0.1)$ than that of atretic cum heavy-atretic, as tested by paired two-sided Student's t-test. The protein content of the follicular wall was fairly constant $( \pm 100 \mu \mathrm{g} / \mathrm{mg}$ of wet weight).

The flattening of dissected non-atretic and atretic together with heavy-atretic follicles was determined by comparing the measured and the expected diameters proportionally. The calculated diameters of non-atretic follicles of the classes 2-5, $5-8$ and $>8 \mathrm{~mm}$ were smaller than measured, being $3.69 \pm 3.56 \mathrm{p} .100$ $(n=26), 6.39 \pm 4.63$ p. $100(n=48)$ and $8.08 \pm 4.16$ p. $100(n=68)$, re- 


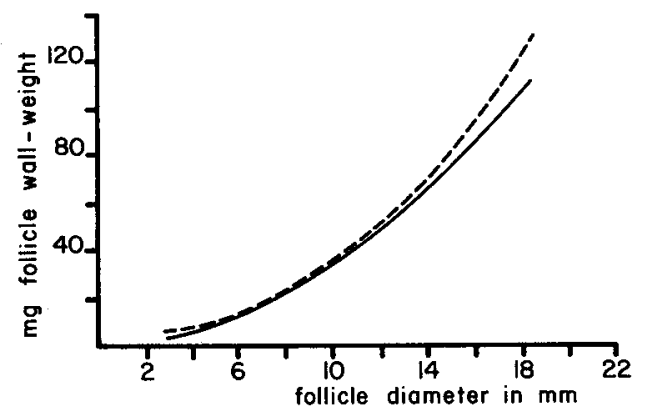

FIG. 5. - Relation between follicle diameter and weight of the follicular wall; polynomial regression for non-atretic folficles $(-\cdots-1): y=-3.7+2.69 x-$ $0.01 x^{2}+0.001 x^{3}$ and for indeterminate cum light-atretic bovine follicles $(-)$ : $y=-0.059+0.62 x+0.30 x^{2}$.

spectively. For the atretic cum heavy-atretic follicles, these percentages were $6.07 \pm 3.46$ p. $100(n=99), 8.19 \pm 4.22$ p. $100(n=81)$ and $10.94 \pm 9.87$ p. 100 ( $\mathrm{n}=41)$, respectively. The oestradiol $-17 \beta$ level in $\mathrm{pmol} / \mathrm{ml}$ of FF of 39 follicles is presented in table 2 . In the selected animal we found very few mediumsized follicles and only one large non-atretic and two large indeterminate follicles. In the group of small follicles ranging from 2 to $5 \mathrm{~mm}$, the oestradiol-17 $\beta$ level varied from $145.3 \mathrm{pmol} / \mathrm{ml}$ in the macroscopically classified non-atretic follicles to $21.7 \mathrm{pmol} / \mathrm{ml}$ in the heavy-atretic ones. The oestradiol-17 $\beta$ level was very high in the large non-atretic follicle and relatively low in the two large indeterminate ones.

\section{TABLE 2}

Oestradiol-173 level* in the fluid of macroscopically classified follicles in the ovaries of a cow in pro-oestrus

\begin{tabular}{|c|c|c|c|c|c|}
\hline $\begin{array}{c}\text { Foll. } \\
\text { diam. } \\
\text { (in } \mathrm{mm} \text { ) }\end{array}$ & non-atretic & indeterminate & light-atretic & atretic & heavy-atretic \\
\hline $2-5 \ldots \ldots$ & $\begin{array}{c}145.3 \pm 40.4 \\
(n=5)\end{array}$ & $\begin{array}{c}122.9 \pm 25.8 \\
(n=4)\end{array}$ & $\begin{array}{c}38.6 \pm 13.3 \\
(n=6)\end{array}$ & $\begin{array}{c}28.2 \pm 5.4 \\
(n=14)\end{array}$ & $\begin{array}{c}21.7 \pm 3.7 \\
(n=7)\end{array}$ \\
\hline 5-8 $\ldots$. & - & - & - & $\begin{array}{c}14.9 \pm 3.7 \\
(\mathrm{n}=4)\end{array}$ & $\begin{array}{l}4.7 \\
(n=1)\end{array}$ \\
\hline$>8$ & $\begin{array}{l}7374.1 \\
\quad(n=1)\end{array}$ & $\begin{array}{c}127.4 \pm 118.5 \\
(n=2)\end{array}$ & - & - & - \\
\hline
\end{tabular}

* as $\mathrm{pmol} / \mathrm{ml} \pm \mathrm{SEM}(\mathrm{n}=$ number of follicles).

\section{Discussion.}

The high correlation between the macroscopic classification and the histological qualification of antral follicles implies that macroscopic criteria offer a highly reliable means of identifying bovine follicles. Exceptions to this are the preovulatory follicles of animals in oestrus, as also mentioned by Moor et al. 
(1978). Preovulatory changes in the micromorphology of the membrana granulosa (Dieleman and Kruip, 1980) and the enormous extension of the theca interna substantially alter the macroscopic appearance of these follicles.

In bovine follicles, the initial structural changes associated with degeneration mainly occur in the membrana granulosa. Degenerations in the basal lamina, theca interna, cumulus and oocyte do not occur until secondary and, principally, tertiary stages of atresia.

Invading macrophages, participating in the removal of granulosa cell debris, appear in the follicles of secondary atresia. The very few, free-floating atretic bodies in follicles of tertiary atresia might be explained by the phagocytotic action of the macrophages. Although judged after fixation in Bouin's fluid, the oocyte in follicles of primary and secondary atresia did not seem to be affected by the process of atresia. This is in agreement with the findings that viable lambs can be born after fertilization of in vitro-matured oocytes of light-atretic follicles (Moor and Trounson, 1977).

It is important to emphasize that classification into several degrees of atresia is imposed upon a continuous sequence of events and therefore that it is sometimes more arbitrary than distinct. Nonetheless, our results indicate that macroscopically classified atretic follicles can be subdivided into three groups. The group of follicles of secondary atresia represents only a large intermediate group of atretic follicles (55.8 p. 100 correlation between macroscopic classification and histological qualification). The low significance in comparing the progression of follicular degeneration and the decrease in wall weight is probably a result of the crude procedure of weighing wet tissue (adherence of follicular fluid and buffer).

The comparison between the diameter of the follicles measured under the stereomicroscope and that based on total follicular weight indicates that dissected follicles will be overestimated by about 5 to $10 \mathrm{p}$. 100 . This might be important in studies on the relation between follicle size and steroid production.

Furthermore, our results indicate that the level of oestradiol-17 $\beta$ is lower in small non-atretic follicles than in large follicles and that it decreases as degeneration increases, independently of follicle size. The striking decline when comparing the oestradiol-17 $\beta$ level in the follicular fluid of large non-atretic follicles and that of large indeterminate follicles, possibly at the onset of primary atresia, indicates that functional degeneration occurs before the micromorphological features show this change. The intermediate position of the follicles classified as indeterminate possibly suggests that the onset of atresia can first be identified by macroscopic criteria such as translucent appearance and vascularization. The data presented here show that the macroscopically determined morphology of bovine follicles reflects their functional character.

Reçu en septembre 1981. Accepté en novembre 1981.

Acknowledgements. - The authors are grateful to Dr. R. M. Moor for his valuable critism in the preparation of this paper. They thank Mr. Th. V. Beneden, Mrs. W. H. R. de Jong and Mr. A. Klarenbeek for their expert technical assistance. They also wish to thank Mr. A. Hofman and Mr. W. Bes for making the photographs. 
Résumé. Des follicules à antrum de bovins, de 2 à $20 \mathrm{~mm}$ de diamètre, libérés du stroma, ont été classés au stéréomicroscope, selon les critères utilisés par Moor et a/. (1978). Un contrôle histologique de la classification macroscopique a été réalisé sur 191 follicules fixés au Bouin, inclus dans la paraffine, coupés transversalement (à travers le cumulus et l'ovocyte) et colorés à l'hematoxyline-éosine. Pour étudier la relation entre les caractéristiques morphologiques déterminées macroscopiquement et la teneur en oestradiol $17 \beta$ (E2) dans le liquide folliculaire (FF) nous avons utilisé 39 follicules d'un animal (E2, exprimé en $\mathrm{pmol} / \mathrm{ml}$ FF a été estimé suivant la méthode RIA). L'homologie entre la classification macroscopique et la qualification histologique des follicules sains et atrétiques est respectivement de 93,3 et 95,5 p. 100. Les petits follicules non atrétiques contiennent moins de E2 que les grands et la teneur en E2 dans le liquide folliculaire diminue d'autant plus que l'atrésie est plus avancée. On en conclut que l'utilisation des critères macroscopiques permet d'obtenir des indications précises sur les caractéristiques micromorphologiques et les aptitudes fonctionnelles des follicules de bovins.

\section{References}

BRAND A., DE JONG W. H. R., 1973. Qualitative micromorphological investigations of the tertiary follicle population during the oestrous cycle in sheep. J. Reprod. Fertil., 33, 431-439.

DIELEMAN S. J., KRUIP Th. A. M., 1980. Relation between 3ß-hydroxy-steroid dehydrogenase activity in preovulatory follicles and steroids present in the follicular fluid during normal and PMS-G/PGF2 $\alpha$ induced oestrus. Yth Int. Congr. Anim. Reprod. \& A.l., Madrid, 1980, Vol. III, p. 31 .

DRIANCOURT M. A., MARIANA J. C., PALMER E., 1981 A rapid technique for the histological examination of large ovarian follicles. Reprod. Nutr. Dévelop., 21, 371-375.

HAY M. F., CRAN D. G., MOOR R. M., 1976. Structural changes occurring during atresia in sheep ovarian follicles. Cell Tiss. Res., 169, 515-529.

HAY M. F., MOOR R. M., CRAN D. G., DOTT H. M., 1979. Regeneration of atretic sheep ovarian follicles in vitro. J. Reprod. Fert., 55, 195-207.

KRUIP Th. A. M., DIELEMAN S. J., MOOR R. M., 1979. Steroid production by bovine follicles in vitro: influence of size, stage of cycle and culture system. Ann. Biol. anim. Bioch. Biophys., 19, 1537-1545.

LOWRY O. H., ROSEBROUGH N. J., FARR A. L., RANDELL ROSE J., 1951. Protein measurement with the folin phenol reagent. J. biol. Chem., 193, 265-275.

MOOR R. M., TROUNSON A. O., 1977. Hormonal and follicular factors affecting maturation of sheep oocytes in vitro and their subsequent developmental capacity. J. Reprod. Fert., 49, 101-109.

MOOR R. M., HAY M. F., DOTT H. M., CRAN D. G., 1978. Macroscopic identification and steroidogenic function of atretic follicules in sheep. J. Endocrinol., 77. 309-318.

RAJAKOSKI E., 1960. The ovarian follicular system in sexually mature heifers with special reference to seasonal, cyclical and leftright variations. Acta endocrinol., Suppl. 52, blz. 1. 